\title{
The Profile of Scientific Literacy in Student's Junior High School 1 Kesamben with Local Wisdom
}

\author{
Ririn Elviana ${ }^{1, *}$ Dadan Rosana ${ }^{2}$, Maya Izzatus Shofa ${ }^{1,}$ Andyta Ma'rifatul Usnia ${ }^{1}$ \\ ${ }^{1}$ Master of Natural Science Education, Faculty of Mathematic and Natural Sciences, Universitas Negeri \\ Yogyakarta, Indonesia \\ ${ }^{2}$ Department of Natural Science Education, Faculty of Mathematic and Natural Sciences, Universitas Negeri \\ Yogyakarta, Indonesia \\ *Corresponding author. Email: ririnelviana@gmail.com
}

\begin{abstract}
This study aims to determine the profile of scientific literacy in student's Junior High School1 Kesamben with local wisdom. This research was quantitative descriptive research. This research was conducted at Junior High School 1 Kesamben. The sample used was random sampling, which was class VIII students of 62 people. The instruments was 15 multiple choice test questions of scientific literacy. The data analysis was performed with a quantitative percentage analysis, so as to determine the category of scientific literacy of each student. The instrument for students consists of 3 aspects with 5 indicators. The results of the analysis of the question found an average of the aspect 1 was 61.8 ; aspect 2 was 50; and aspect 4 amounting to 31.2. The average of this result indicates level of scientific literacy is 49 which belongs to the medium category. Then based on these analysis of each of these aspect and indicators of scientific literacy can be concluded that needed teaching materials integrated with local wisdom.
\end{abstract}

Keywords: Scientific literacy, Local wisdom

\section{INTRODUCTION}

The Indonesian education system is currently experiencing a downturn, especially in the education system. According to the World Economic Forum (WEF) which published The Global Competitiveness Report 2012-2013 on the global competitiveness index and its constituent elements, Indonesia is in fifth position among ASEAN countries, while Indonesia is in 50th position out of 144 countries in 2012 at the world level, 46 out of 142 countries in 2011 and 44 in 2010. This means that for 3 consecutive years it has experienced a significant decline. Indonesia's condition is exacerbated by the achievement of Indonesian students in the literacy aspect as reported by TIMSS (Trends in International Mathematics and Science Study) and PISA (Program for International Student Assessment) that Indonesia is in the 4th position from the bottom of several reports since 1999 [1].

The latest PISA report obtained from the OECD states that there is still low knowledge in the ability to be able to use basic science knowledge to interpret data and explain valid scientific conclusions [1]. This shows that students in science learning are still unable to use basic science knowledge to analyze data and describe valid scientific conclusions. Based on these conditions, it is very necessary to improve the scientific literacy of students [2], [3].

Science literacy is the ability to engage with science issues and ideas as a thinking citizen. Scientific literacy can teach citizens to make decisions in everyday life through an assessment of scientific information and concepts [3]. Scientific literacy is an act of understanding science and applying it to the needs of society. Science literacy needs to be owned by students so that schools are expected to implement scientific literacy activities systematically [4]. Scientific literacy consists of knowledge and understanding of scientific concepts and the process of making decisions that are useful for society, culture and economy. The position of scientific literacy which is very important for the future, the curriculum in science learning should be more directed in accordance with the perspective of a scientific literacy framework in accordance with the concepts that have been put forward by PISA [5]. 
Science learning should be collaborated with the daily lives of students (contextual). One of the efforts to make science learning contextual is to use local materials. The implementation of the 2013 Curriculum requires a lot of attention, one of which is paying attention to the diversity of wisdoms and characteristics of the regions, the environment, national unity, and the values of life (living values). Education is directed at building living values and national insight of students which become an important foundation for efforts to maintain national unity and integrity within the framework of the Unitary State of the Republic of Indonesia, one of which can be pursued through the development of learning by combining local wisdom [4],

Local wisdom material is a substance (object) contained in a particular locale that can be used for certain purposes [7]. Local wisdom material can be local wisdom. Local material which is local wisdom can take the form of cultural heritage, namely the results or activities of certain communities. Rich local material in an area can be used as a learning resource [5]. Local wisdom can also be interpreted as basic knowledge obtained from a life in balance with nature. Preserved local wisdom will be able to inhibit the negative effects of globalization and modernization, which reduce the behavior of young people, especially students [8].

Based on the description of economic and educational problems, it is important to develop an integrated IPA Subject Specific Pedagogics (SSP) local wisdom in Kampung Toga in order to increase students' scientific literacy towards Biopharmaca knowledge. Before the development of the SSP it is important to know the profile of the students' scientific literacy. This study aims to determine the initial profile of the student's scientific literacy level, to analyze the development needs and increase of students' scientific literacy using the local wisdom of the Toga village. And for further planning the research will develop SSP using KD 3.4. regarding the structure and function of plants integrated with the local wisdom of the Toga village.

\section{RESEARCH METHOD}

This research used quantitative descriptive research. This research was conducted at Junior High School 1 Kesamben, Blitar Regency. The sample used random sampling from junior high school, which is class VIII students of 62 people. The instruments was 15 multiple choice test questions of scientific literacy. The data analysis was performed with a quantitative percentage analysis, so as to determine the category of scientific literacy of each student. The category of students' scientific literacy can be seen in table 1 [9]. In this research, the analysed indicators of critical thinkingis include context, content and knowledge

Table 1 The category of scientific literacy [9]

\begin{tabular}{|c|l|}
\hline Interval & \multicolumn{1}{|c|}{ Category } \\
\hline $80-100$ & Very high \\
\hline $61-80$ & High \\
\hline $41-60$ & Medium \\
\hline $21-40$ & Low \\
\hline $0-20$ & Very low \\
\hline
\end{tabular}

\section{RESULTS AND DISCUSSION}

This study aims to analyze the level of scientific literacy of students at Junior High School 1 Kesamben. There are several indicators analyzed which consist of the following:

Table 2 Aspects and indictors of scientific literacy

\begin{tabular}{|l|l|}
\hline \multicolumn{1}{|c|}{ Aspect } & \multicolumn{1}{|c|}{ Indicator } \\
\hline Context & $\begin{array}{l}\text { Describes Personal, Local and } \\
\text { Global issues }\end{array}$ \\
\hline \multirow{2}{*}{ Competence } & Explain phenomena scientifically. \\
\cline { 2 - 2 } & $\begin{array}{l}\text { Evaluating and designing scientific } \\
\text { investigations }\end{array}$ \\
\cline { 2 - 2 } & $\begin{array}{l}\text { Interpret evidence and data } \\
\text { scientifically }\end{array}$ \\
\hline Knowledge & $\begin{array}{l}\text { Explain the concept of the } \\
\text { material being studied }\end{array}$ \\
\hline
\end{tabular}

Based on table 2, it is known that there are 3 aspects and 5 indicators of scientific literacy that are observed in this study. In order to make the results of data easier to read, it will be shown in Figure 1.

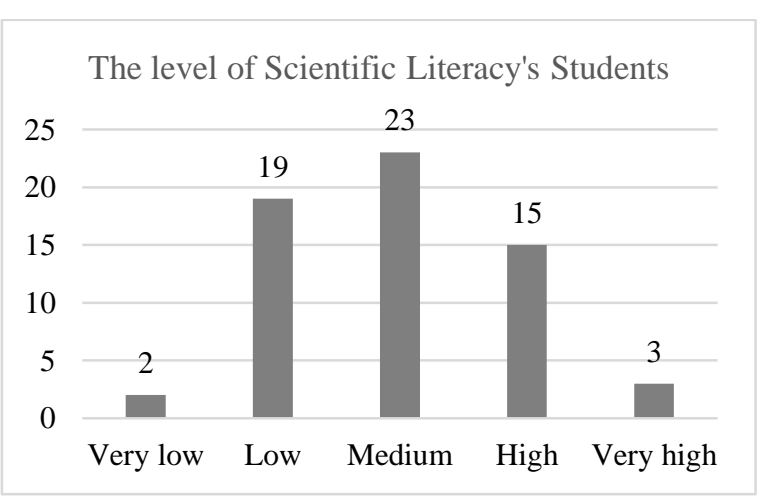

Figure 1 The graph of level of scientific literacy's students 
Based on the Figure 1, it is known that the number of students who have the highest number are students in the medium category. This condition shows that the literacy level of the students still needs to be improved. By developing the necessary devices or media [10]. However, to find out the specifics, the description of the assessment will be described based on aspects and indicators of scientific literacy.

\subsection{The Results of The Context Aspect}

In the context aspect, there is 1 indicator, namely Describes Personal, Local and Global issues. The results from the context aspect will be described in figure 2 .

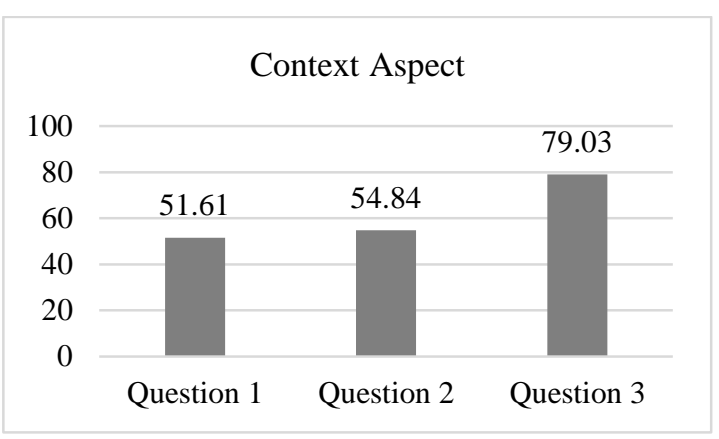

Figure 2 The graph of the context aspect

Based on the table, it is known that the Describes Personal, Local and Global issues indicator has 3 questions with an average value of 61.8 so that it includes into the high category. Based on these results, it can be concluded that the context aspect also needs to be improved.

\subsection{The results of the competency aspects}

In the competency aspect, there are 3 indicators and consist of 9 questions. Indicators of competency aspects consist of; The following are the results of Explain the phenomenon scientifically, Evaluating and designing scientific investigations and Interpret evidence and data scientifically.

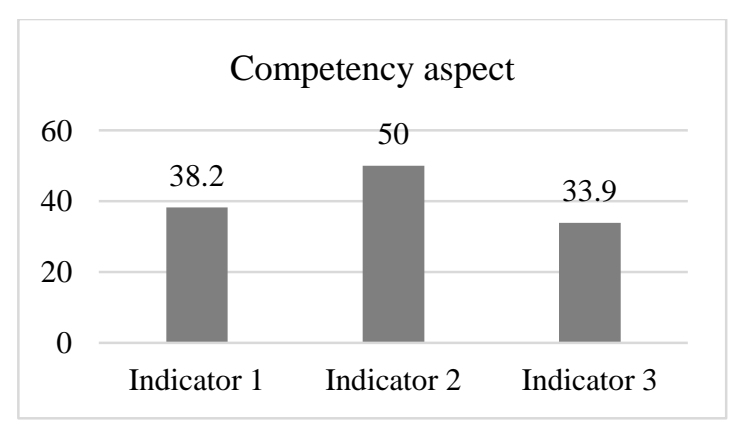

Figure 3 The graph of the competency aspects
Based on the Figure 3, it is known that the competency aspect has 3 indicators with an average value with an average value of 50 so that it falls into the medium category. Based on these results, it can be concluded that the context aspect also needs to be improved.

\subsection{The results of the knowledge aspects}

In the knowledge aspect, there is one indicator, namely Explain the concept of the material being studied. The results of the knowledge aspect will be described in figure 4 :

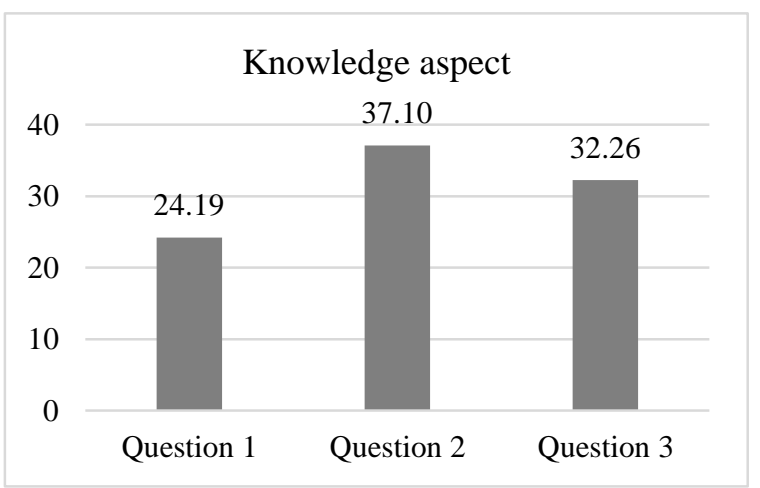

Figure 4 The graph of the knowledge aspects

Based on the Figure 4, it is known that the indicator Explain the concept of the material being studied has 3 questions with an average value of 31.2 so that it falls into the low category [9]s. Based on these results, it can be concluded that the context aspect also needs to be improved. Based on the data that has been obtained, it becomes very important when we want to improve students' scientific literacy, so we are obliged to pay attention to which parts of the aspects are still very low. Then we will improve it by using methods and methods that are appropriate to the theme and material being studied [11].

Scientific literacy has 3 dimensions of assessment that are used to determine student achievement. This dimension consists of the logical conclusion of the learners, the extent to which the phenomenon is explained (by combining biology, physics and chemistry) and its proximity to the environmental phenomenon [2]. It is important to make an assessment of scientific literacy, because scientific literacy is one of the domains that must be developed in the $21 \mathrm{st}$ century [12]. This shows that scientific literacy is used as a means of thinking solutions, understanding scientific concepts and processes to make decisions, maintaining the integrity of local wisdoms. linked to science and increase economic productivity [13]. 
Scientific literacy includes knowledge from science, knowledge of science, fundamental understanding of scientific concepts, understanding inquiry and natural explanation of science [6]. Adolphus explain that someone who has scientific literacy is required to have the following competencies: (1) explain a phenomenon scientifically; (2) evaluate and design understanding of science through inquiry. (3) interpret data and show scientific evidence.

Science learning can use the local wisdom of an area, such as the typical types of plants around the Gunung Kidul coast, which are thorny pandanus plants and prawn cypress, which are an effort to explain to students the concept of science contextually [7]. The application of local wisdom in science learning has certain advantages, namely that it can provide direct experience for students in exploring information creatively and providing deep understanding, thus making learning more meaningful and able to improve students' critical thinking skills [14]. Besides being able to improve learning outcomes through the application of contextual learning integrated with local wisdoms, it will also be able to increase love and concern for the environment [7], [15].

Activities to explore cultural wisdom that have a direct relationship with the themes in science lessons in schools will provide a clear and relevant picture between learning materials, educators, and students. Interesting learning resources can improve students' understanding, such as the local wisdom of the toga village in Blitar district. Blitar is a Regency and City located in East Java Province. This toga village tourism village is a village which apart from being an educational tourism village about various types of family medicinal plants, is also a production site for various Toga preparations such as candy, syrup, drinks and toga chocolate.

Based on the conditions and concepts used in the toga village, which studies the structure and function and benefits of each type of toga plant, it is hoped that it will be able to improve students' scientific literacy towards biopharmaceutical plants. Science and biology materials related to plant culture and function will be very important when we want to try to develop students' scientific literature.

\section{CONCLUSSION}

There are 3 aspects that make the research focus, and consists of 5 indicators, which are then made into 3 questions for each indicator. Overall, the scientific literacy profile of students of Junior high school 1
Kesamben has a very low level, namely with an average value of 49 . So it is necessary to increase scientific literacy by linking with the use of e modul integrated local wisdoms of Toga village.

\section{REFERENCES}

[1] OECD, PISA 2015: Assesment and Analytical Framework: Science, Reading, Mathematic and Financial Literacy. OECD Publishing, 2016. DOI: https://doi.org/10.1787/19963777

[2] A. Pramuda, Mundilarto, H. Kuswanto, S. Hadiati, Effect of Real-Time Physics Organizer Based Smartphone and Indigenous Technology to Students' Scientific Literacy Viewed From Gender Differences, International Journal Instrument 12 (2019) 253-270. DOI: https://doi.org/10.29333/iji.2019.12316a

[3] J. F. Shaffer, J. Ferguson, K. Denaro, Use of The Test of Scientific Literacy Skills Reveals That Fundamental Literacy is an Important Contributor to Scientific Literacy, CBE Life Science Eduction 18(3) (2019) 31-39. DOI: https://doi.org/10.11591/ijere.v8i4.20312

[4] F. M. Sya'ban and I. Wilujeng, Pengembangan SSP Zat dan Energi Berbasis Keunggulan Lokal untuk Meningkatkan Literasi Sains dan Kepedulian Lingkungan, Jurnal Inovasi Pendidikan IPA 2(1) (2016) 66-75. DOI: http://dx.doi.org/10.21831/jipi.v2i1.8369

[5] E. Sobiatin, M. Tibrani, N. Aznam, A. T. Saputra, and M. Fatharani, The integration of Palembang's local wisdom in natural science learning materials, Journal of Physics Conference Series, vol. 1440, IOP Publishing, Bristol, 2020, 17-27. DOI: $\quad$ http://dx.doi.org/10.1088/1742$\underline{6596 / 1440 / 1 / 012106}$

[6] R. Bybee, B. Mccrae, R. Laurie, PISA 2006 : An Assessment of Scientific Literacy, Wiley Journal 46(8) (2009) 865-883. DOI: http://dx.doi.org/10.1002/tea.20333

[7] R. Marlina, B. Hardigaluh, and M. Yokhebed, Pengembangan Modul Pengetahuan Lingkungan Berbasis Potensi Lokal Untuk Menumbuhkan Sikap Peduli Lingkungan Mahasiswa Pendidikan Biologi, Jurnal Pengajaran Matatematika dan Ilmu Pengetahuan Alam 2(1) (2015) 16-29. DOI: http://dx.doi.org/10.18269/jpmipa.v20i1.569

[8] X. Gu, C. Wang, and L. Lin, Examining Scientific Literacy Through New Media, Eurasia 
Journal Mathematic and Science 15 (2019) 1522. DOI: http://dx.doi.org/10.29333/ejmste/109948

[9] S. Ridho, N. S. Aminah, and A. Supriyanto, The Profile of Scientific Literacy Skill Student at SMA Batik 2 Surakarta, Jurnal Penelitian Pengembangan Pendidikan Fisika 4(20 (2018) 47-54. DOI: http://dx.doi.org/10.21009/1.04201

[10] S. Naganuma, An assessment of civic scientific literacy in Japan: Development of a More Authentic Assessment Task And Scoring Rubric, International. Journal of Science Education 7(4) (2017) 301-322. DOI: $\underline{\text { http://dx.doi.org/10.1080/21548455.2017.13231 }}$ $\underline{31}$

[11] A. Fasce and A. Picó, Science as a Vaccine: The Relation between Scientific Literacy and Unwarranted Beliefs, Science Education 28 (2019) 109-125 DOI: http://dx.doi.org/10.1007/s11191-018-00022-0

[12] L. Bang, In the maw of the Ouroboros: an analysis of scientific literacy and democracy, Culture Study Science Education 13(3) 2018) 807-822. DOI: http://dx.doi.org/10.1007/s11422-017-9808-2

[13] M. Nofiana, T. Julianto, Upaya Peningkatan Literasi Sains Siswa Melalui Pembelajaran Berbasis Keunggulan Lokal, Biosfer: Jurnal Tadris Biologi 9(1) (2018) 24-32. DOI: http://dx.doi.org/10.24042/biosf.v9i1.2876

[14] A. Anisa, Meningkatkan Keterampilan Berpikir Kritis Peserta Didik melalui Pembelajaran IPA Berbasis Potensi Lokal Jepara, Jurnal Inovasi Pendidikan IPA 3(1) (2017) 17-29. DOI: http://dx.doi.org/10.21831/jipi.v3i1.8607

[15] I. Wilujeng, P. Zuhdan Kun, and I. G. P. Suryadarma, Science learning based on local wisdom: Overview of the nature of science (NoS) achieved, AIP Conference Proceeding, vol. 1868, AIP Publishing, College park, Maryland, 2017, pp. 124-135. DOI: http://dx.doi.org/10.1063/1.4995189 